\title{
The utilization and management of plant resources in rural areas of the Limpopo Province, South Africa
}

\author{
Marula T Rasethe, Sebua S Semenya*, Martin J Potgieter and Alfred Maroyi
}

\begin{abstract}
Background: Most rural people in the Limpopo Province depend on plant resources to meet their livelihood needs. However, there is insufficient recorded information regarding their use and management. The current study therefore was carried out in selected villages of the Limpopo Province, to close this knowledge gap.

Methods: Information was collected from 60 people residing in two villages, using a semi-structured questionnaire, supplemented with field observations.

Results: A total of 47 wild plant species (95\% indigenous and 5\% exotics) from 27 families, mostly from the Fabaceae (17\%), Anacardiaceae (9\%), and Combretaceae (9\%) were documented. These species were used primarily for firewood (40\%), food (36\%) and medicine (29\%). Significantly used species included Sclerocarya birrea (85\%), Combretum kraussii (35\%) and Harpephyllum caffrum (35\%). Local traditional rules and regulations including taboos, social beliefs and fines are in place to aid in the management of communal resources. However, a significant number (67\%) of participants mentioned that they were not pleased with these rules and regulations.

Conclusion: The current study concluded that plant resources still play an important role in the surveyed rural areas of the Limpopo Province. Furthermore, for sustainable utilization and long-term conservation of plants in these areas the government should assist communities in the management of their plant resources.
\end{abstract}

Keywords: Conservation, Management, Plant resources, Limpopo Province, South Africa

\section{Background}

Since time immemorial, Africans have gathered plant resources to meet their livelihood needs [1]. These resources include amongst others food, fodder, construction material, and fibres for clothing [2]. This heavy dependency on plant resources is largely conditioned by various factors that include their accessibility and socio-cultural value [3]. Even today, studies [4-10] have noted the dependency of a large part of the African population on gathered plant resources [11].

Africans in the rural Limpopo Province of South Africa are still very dependent on their local environment to meet their daily livelihood needs [12]. However, there is still a dearth of recorded information about communal use of plant resources, as well as its management by, and

\footnotetext{
* Correspondence: Sebuasemenya@gmail.com

Department of Biodiversity, University of Limpopo, Private Bag X1106, Sovenga 0727, South Africa
}

(c) 2013 Rasethe et al.; licensee BioMed Central Ltd. This is an Open Access article distributed under the terms of the Creative Commons Attribution License (http://creativecommons.org/licenses/by/2.0), which permits unrestricted use, distribution, and reproduction in any medium, provided the original work is properly cited. perceptions of adopted management strategies by local communities. According to Ramakrishnan [13], local people's perceptions of, plant biodiversity and its management influence the type of interactions they have with their surroundings, which ultimately play an important role in local conservation efforts [14].

Therefore, the aim of this study was to document the use of plant resources by people in two rural villages of the Limpopo Province, and explore perceptions towards adopted management of these resources. Findings of this study will assist to define the "plant-people relationship" that is important for the ultimate sustainable utilization of plant resources in the Limpopo Province.

\section{Methods}

\section{Study area}

The study was conducted in two villages situated in the Capricorn (Monywaneng) and Mopani (Ga-Sekgopo)

\section{Biomed Central}


districts of the Limpopo Province. Monywaneng village is situated $30 \mathrm{~km}$ north-west of the city of Polokwane, and Ga-Sekgopo $80 \mathrm{~km}$ north east of Polokwane (Figure 1). These two villages were selected as representatives of both peri-urban (Monywaneng) and rural (Ga-Sekgopo), thus covering the socio-economic spectrum of communities that rely on their surrounding vegetation for their livelihood.

The interviewed people in the present study are from the Bapedi ethnic group. According to Monning [15], this ethnic group depend on natural plant resources to meet their different needs such as food, furniture, fuelwood and fibre. Semenya et al. [16], noted that Bapedi people are heavily reliant the medicinal plants, either alone or in combination, with orthodox medicines for the treatment of several diseases.

\section{Description of vegetation types}

The vegetation in the studied areas is classified as semiarid savannas [17], characterized by a mixture of trees, shrubs and grasses [18]. This type of vegetation provides a diverse flora with rich useful plant species that the people of the study areas utilise to meet their livelihood needs. Dominant tree genera include Acacia, Albizia, Combretum, Gymnosporia, Grewia, Sclerocarya and Terminalia.

\section{Climate}

Generally, the studied villages; Ga-Sekgopo and Monywaneng have a semi-arid type of climate [19]. They are located in a summer rainfall region where the rainfall occurs in the form of heavy thunderstorms or soft rain. These villages receive almost $90 \%$ of their total annual rainfall during the summer period, from October to March [20].

Regarding the daily temperatures in the studied villages; they vary from mid-20's to mid-30's, with an average range of between $17^{\circ}$ and $27^{\circ} \mathrm{C}$ in the summer and $4^{\circ}$ to $20^{\circ} \mathrm{C}$ in the winter [20]. Furthermore, hail and frost rarely occurs.

\section{Sampling and data collection}

Thirty adults of various ages, but older than 21, were randomly selected per village to participate in this study.
Sepedi, the local dialect, was used to inform participants about the nature of the study. Prior to data collection verbal consent was obtained from each participant. Ethical conduct was insured by following the principles contained in the Code of Ethics of the University of Limpopo, and International Society of Ethnobiology [21].

Subsequently, data was collected (January to June 2012) using a semi-structured questionnaire. The questionnaire was designed to gather data on various aspects relating to the use of plant resources and people's perception towards current vegetation management strategies in their local areas. For instance, aspects relating to plant utilization (different uses of plant resources, source of plant and harvesting frequency of plants), and those relating to adopted local management for plants (current management adopted in the studied villages, participant's perceptions/attitudes or opinion on current management practices), and other related information were documented.

\section{Specimen collection and personal observations}

After interviewing participants, they escorted the researcher to the field for plant identifications. Plants were initially identified by participants with their vernacular names. Collected specimens were later validated at the Larry Leach Herbarium (UNIN) of the University of Limpopo. Collection numbers of species are presented in Table 1.

\section{Data analysis}

Collected data were carefully checked by researchers for completeness and reliability. Descriptive statistics such as frequencies and percentages were used in the analysis of the data. Information obtained from the International Plant Index (IPNI) [22] was used to validate the documented species and to establish their families.

\section{Results and discussion \\ Diversity of plants species used}

Forty seven species belonging to 41 genera and 27 botanical families, were documented as being used by participants in the two surveyed villages (Table 1). With the
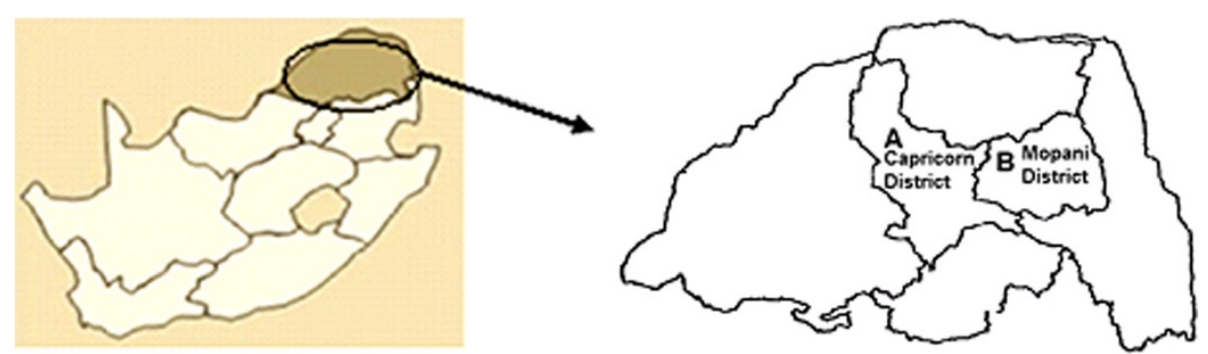

Figure 1 Localities of (A) Monywaneng and (B) Ga-Sekgopo villages in the Limpopo Province, South Africa. 
Table 1 Useful species used by people in Ga-Sekgopo and Monywaneng villages

\begin{tabular}{|c|c|c|c|c|c|c|c|}
\hline Species name & $\begin{array}{l}\text { Collection } \\
\text { no }\end{array}$ & $\begin{array}{l}\text { Vernacular } \\
\text { name }\end{array}$ & Family & $\begin{array}{l}\text { Utilization } \\
\text { category }\end{array}$ & Ga-Sekgopo & Monywaneng & $\begin{array}{l}\text { Frequency } \\
(\%)\end{array}$ \\
\hline Acacia karroo Hayne & $43 \mathrm{MT}$ & Mushu & Fabaceae & Firewood & - & + & 22 \\
\hline Acacia rehmanniana Schinz & $20 \mathrm{MT}$ & Mosibihla & Fabaceae & Firewood & - & + & 15 \\
\hline Aloe greatheadii Schönland var. greatheadii & $16 \mathrm{MT}$ & Sekgopha & Aloaceae & Medicine & + & + & 22 \\
\hline Asparagus suaveolens Burch. & $04 \mathrm{MT}$ & Sephatlalatsa & Asparagaceae & Medicine & + & - & 08 \\
\hline Bauhinia galpinii N.E.Br & $28 \mathrm{MT}$ & Motswiriri & Fabaceae & Medicine & - & + & 05 \\
\hline Berchemia discolor (Klotzsch) Hemsl. & $34 \mathrm{MT}$ & Mogwahlapa & Rhamnaceae & Firewood & + & - & 35 \\
\hline \multirow[t]{2}{*}{ Burkea africana Hook. } & $42 \mathrm{MT}$ & Monatlo & Fabaceae & Firewood & + & - & 17 \\
\hline & & & & Medicine & + & - & 05 \\
\hline \multirow[t]{2}{*}{ Carissa edulis (Forssk.) Vahl } & $36 \mathrm{MT}$ & Mothokolo & Apocynaceae & Firewood & - & + & 02 \\
\hline & & & & Fruit & + & - & 10 \\
\hline $\begin{array}{l}\text { Combretum apiculatum Sond. subsp. } \\
\text { Apiculatum }\end{array}$ & $19 \mathrm{MT}$ & Khuditshwane & Combretaceae & Firewood & + & - & 07 \\
\hline Combretum hereroense Schinz & $22 \mathrm{MT}$ & Mokabe & Combretaceae & Firewood & + & - & 02 \\
\hline Combretum kraussii Hochst. & $11 \mathrm{MT}$ & Moduba & Combretaceae & Firewood & + & + & 35 \\
\hline \multirow[t]{2}{*}{ Clerodendrum glabrum E.Mey. } & $18 \mathrm{MT}$ & Mohlokohloko & Verbenaceae & Crafting & + & - & 03 \\
\hline & & & & Timber & + & - & 02 \\
\hline Commiphora mollis (Oliv.) Engl. & $32 \mathrm{MT}$ & Mokgorokgoro & Burseraceae & Crafting & - & + & 02 \\
\hline Cryptocarya sp. & $47 \mathrm{MT}$ & Morobarobe & Lauraceae & Medicine & - & + & 07 \\
\hline Dichrostachys cinerea (L.) Wight \& Arn. & $12 \mathrm{MT}$ & Moretshe & Fabaceae & Firewood & + & + & 22 \\
\hline Diospyros lycioides Desf. subsp. Lycioides & $17 \mathrm{MT}$ & Setlommana & Ebenaceae & Fruit & + & - & 07 \\
\hline $\begin{array}{l}\text { Dombeya rotundifolia (Hochst.) Planch. } \\
\text { var. rotundifolia }\end{array}$ & $01 \mathrm{MT}$ & Mogokobu & Sterculiaceae & Firewood & - & + & 10 \\
\hline Ehretia rigida (Thunb.) Druce subsp. Rigida & $25 \mathrm{MT}$ & Morobe & Boraginaceae & Fruit & - & + & 13 \\
\hline Eucalyptus grandis W.Hill ex Maiden & $15 \mathrm{MT}$ & Motlouma & Myrtaceae & Firewood & + & - & 02 \\
\hline Euclea crispa Gürke subsp. crispa & 33 MT & Mkwerekwere & Ebenaceae & Crafting & - & + & 03 \\
\hline Euclea undulate Thunb. & $46 \mathrm{MT}$ & Mohlakola & Ebenaceae & Fruit & - & + & 10 \\
\hline Ficus ingens (Miq.) Miq. & $08 \mathrm{MT}$ & Monokane & Moraceae & Fruit & + & - & 12 \\
\hline Flacourtia indica (Burm.f.) Merr. & $38 \mathrm{MT}$ & Morethema & Flacourtiaceae & Fruit & + & - & 02 \\
\hline \multirow{2}{*}{$\begin{array}{l}\text { Flueggea virosa (Roxb. ex Willd.) Voigt } \\
\text { subsp. Virosa }\end{array}$} & $44 \mathrm{MT}$ & Mohlakauma & Phyllanthaceae & Fruit & + & + & 05 \\
\hline & & & & Crafting & + & - & 03 \\
\hline Grewia bicolor Juss. var. bicolor & $30 \mathrm{MT}$ & Morethwa & Malvaceae & Fruit & + & + & 15 \\
\hline \multirow[t]{2}{*}{ Grewia retinervis Burret } & $02 \mathrm{MT}$ & Mpharatshwene & Malvaceae & Firewood & + & - & 05 \\
\hline & & & & Medicine & + & - & 02 \\
\hline Gymnosporia senegalensis (Lam.) Loes. & $37 \mathrm{MT}$ & Sephathwa & Celastraceae & Medicine & + & - & 02 \\
\hline \multirow[t]{2}{*}{ Gymnosporia sp. } & $21 \mathrm{MT}$ & Moritidi & Celastraceae & Firewood & + & - & 08 \\
\hline & & & & Crafting & + & - & 02 \\
\hline \multirow[t]{2}{*}{ Harpephyllum caffrum Bernh. ex Krauss } & $27 \mathrm{MT}$ & Motshidi & Anacardiaceae & Firewood & - & + & 07 \\
\hline & & & & Fruit & + & + & 28 \\
\hline Indigofera sp. & $31 \mathrm{MT}$ & Morotelashotsi & Fabaceae & Medicine & - & + & 05 \\
\hline Kleinia longiflora DC. & 03 MT & Mmale & Asteraceae & Medicine & - & + & 05 \\
\hline Lannea discolor (Sond.) Engl. & $05 \mathrm{MT}$ & Mokgothwane & Anacardiaceae & Fruit & - & + & 05 \\
\hline Lippia javanica (Burm.f.) Spreng. & $06 \mathrm{MT}$ & Mosunkwane & Verbenaceae & Medicine & + & + & 08 \\
\hline Melia azedarach L. & $40 \mathrm{MT}$ & Mobidi & Meliaceae & Firewood & - & + & 10 \\
\hline Opuntia ficus-indica (L.) Mill. & $41 \mathrm{MT}$ & Motloro & Cactaceae & Fruit & + & + & 05 \\
\hline
\end{tabular}


Table 1 Useful species used by people in Ga-Sekgopo and Monywaneng villages (Continued)

\begin{tabular}{|c|c|c|c|c|c|c|c|}
\hline Pappea capensis Eckl. \& Zeyh. & $10 \mathrm{MT}$ & Morothodi & Sapindaceae & Fruit & + & - & 05 \\
\hline Peltophorum africanum Sond. & $45 \mathrm{MT}$ & Mosehla & Leguminosae & Firewood & - & + & 10 \\
\hline Philenoptera violacea (Klotzsch) Schrire & $60 \mathrm{MT}$ & Mphato & Leguminosae & Firewood & + & + & 13 \\
\hline Ptaeroxylon obliquum (Thunb.) Radlk. & $23 \mathrm{MT}$ & Molope & Rutaceae & Fruit & + & - & 13 \\
\hline Rhigozum brevispinosum Kuntze. & $29 \mathrm{MT}$ & Not available & Bignoniaceae & Medicine & - & + & 02 \\
\hline Sansevieria sp. & $30 \mathrm{MT}$ & Mokgosi & Dracaenaceae & Crafting & + & - & 02 \\
\hline \multirow{3}{*}{$\begin{array}{l}\text { Sclerocarya birrea (A.Rich.) Hochst. subsp. } \\
\text { caffra (Sond.) }\end{array}$} & \multirow[t]{3}{*}{$13 \mathrm{MT}$} & \multirow[t]{3}{*}{ Morula } & \multirow[t]{3}{*}{ Anacardiaceae } & Fruit & + & + & 33 \\
\hline & & & & Firewood & - & + & 42 \\
\hline & & & & Medicine & + & + & 10 \\
\hline $\begin{array}{l}\text { Searsia leptodictya (Diels) T.S.Yi, } \\
\text { A.J.Mill. \& J.Wen }\end{array}$ & $07 \mathrm{MT}$ & Mohlohlo & Anacardiaceae & Fruit & - & + & 08 \\
\hline Senna petersiana (Bolle) Lock. & $26 \mathrm{MT}$ & Monepenepe & Fabaceae & Medicine & + & + & 05 \\
\hline Solanum lycopersicum L. & 09 MT & Motamati & Solanaceae & Medicine & + & - & 02 \\
\hline Vangueria infausta Burch. subsp. Infausta & $24 \mathrm{MT}$ & Mmilo & Rubiaceae & Fruit & + & + & 17 \\
\hline \multirow{2}{*}{$\begin{array}{l}\text { Ziziphus mucronata Willd. subsp. } \\
\text { Mucronata }\end{array}$} & \multirow[t]{2}{*}{$14 \mathrm{MT}$} & \multirow[t]{2}{*}{ Mokgalo } & \multirow[t]{2}{*}{ Rhamnaceae } & Firewood & - & + & 12 \\
\hline & & & & Fruit & + & + & 03 \\
\hline
\end{tabular}

KEY: + :Species is used, - : Species is not used.

exclusion of Melia azedarach and Opuntia ficus-indica, all the recorded species are indigenous to South Africa. Among the botanical families, the most used species came from the Fabaceae (17\%), Anacardiaceae (9\%), and Combretaceae (9\%). This observation is in partial agreement to that of Semenya and Maroyi et al. [23] in different districts of the Limpopo Province, they noted the dominance of Anacardiaceae and Fabaceae. These families, which are mostly trees, play a vital economic role in the present study, in being used either as fuelwood, in crafting, or as medicinal species, and are thus highly preferred.

The species recorded in the studied villages were utilized by participants for firewood (40\%), fruits (36\%), medicine (29\%), crafting purposes (12\%) and timber (2\%). It is worth noting that $15 \%$ of these species were multi-used. This finding is in agreement with other studies $[24,25]$ in the Limpopo Province. Species predominantly used for firewood include Sclerocarya birrea (42\%), Berchemia discolor (35\%), Combretum kraussii (35\%), Acacia karroo and Dichrostachys cinerea (22\% each). With the exclusion of S. birrea, which is exclusively used because of its local availability, all these species are mainly used due to both their local availability and long burning period, which provide lasting heat and light. The extensive use of $S$. birrea and $D$. cinerea for firewood came as no surprise as it was also listed by Madubansi and Shackleton [26] as amongst the highly preferred species for firewood by people in five villages of Bushbuckridge in the Limpopo Province. These species are preferred because they have relatively dense wood that burns well with little smoke [26].
The finding that residents in the investigated villages extensively use $S$. birrea for firewood is unfortunate as this species is protected in terms of the National Forests Act of 1998 (Act 84 of 1998) of South Africa. In terms of this Act, species may not be cut, disturbed, damaged or destroyed and their products may not be possessed, collected, removed, transported, exported, donated, purchased or sold - except under license granted by the Department of Water Affairs and Forestry [27].

The most preferred fruit species include S. birrea (33\%), Harpephyllum caffrum (28\%), Vangueria infausta (17\%), Grewia bicolor (15\%), Ehretia rigida (13\%), Ptaeroxylon obliquum (13\%) and Ficus ingens (12\%). According to the participants, information on the use of these species was acquired through their parents and grandparents from a very early childhood. The extensive exploitation of some of these species is not restricted to the current study. They are commonly harvested for their fruits by different ethnic groups [28-30] residing in various geographical areas of South Africa.

Results of this study further indicated that Aloe greatheadii $(22 \%)$ and S. birrea (10\%) are the most preferred species used for medicinal purposes. The possible efficacy of $A$. greatheadii is confirmed by Botes [31] who extracted the different compounds (organic acid, polyphenols/phenolic acid, alcohol, aldehyde, ketone, alkane, pyrimidine, indole, alkaloid, phytosterol, fatty acid, dicarboxylic acid contents and antioxidants), which are known to have various healing properties. The effectiveness of Sclerocarya birrea to serve as a medicinal plant is culturally validated through its use by various $[4,32-36]$ southern African cultures. However, because $S$. birrea is multi-used 
for medicine, firewood and food, its future utilisation should proceed with caution in order to ensure long term sustainable use. In this regard communication between environmental agencies and local communities is vital.

The same is true with other of species which are multi-used. These species are Burkea. africana (firewood and medicine), Carissa edulis (firewood and fruit), Clerodendrum glabrum (crafting and timber), Grewia retinervis (firewood and medicine), Gymnosporia sp. (firewood and crafting), H. caffrum (firewood and fruit), and Ziziphus mucronata (firewood and fruit). Semenya [37] noted that the multi-utilization of a single species has disadvantages from a conservation point of view because it amplifies its harvesting pressure, thereby posing a threat. This fact is supported by Shanley and Luz [38], who observed that the multi-utilization of some single forest plants for firewood, medicine, crafting and timber has resulted in their decline and extinction in the Eastern Amazonia.

\section{Use of species per village}

The number of plant species used by the participants in the two studied villages differs considerably (Table 1). More species were recorded in Ga-Sekgopo (77\%) than in Monywaneng (67\%). This difference might be an indication of the value and extent of reliance on plant biodiversity between the two communities.

However, species such as A. greatheadii, C. edulis, Combretum kraussii, D. cinerea, Flueggea virosa, Grewia bicolor, $H$. caffrum, Lippia javanica, O. ficus-indica, Philenoptera violacea, $S$. birrea, $V$. infausta and $Z$. mucronata were common in both villages. Their widespread use might be linked to their distribution or natural occurrence; an aspect that warrants further investigation.

\section{Source of plants}

Sixty percent of people in both Monywaneng and Ga-Sekgopo mentioned that they collect plants from communal areas. The most common reasons for the preferences of this land include free access to plants, especially those used for firewood. Firewood is highly used as an alternative source of energy (due to the high cost of electricity) for cooking, boiling water, and heating houses. However, participants complained about the increased distance to collection sites, and availability of certain species compared to the past. This has resulted in them harvesting material from nearby communities, thus initiating conflict with those communities. Those community members who did not collect material in communal areas cited the availability of electricity, unavailability of preferred species, and safety factors. A study by Paumgarten and Shackleton et al. [39] in various areas of South Africa, found that those villagers who did not utilise communal areas for livelihood needs tended to purchase medicine, firewood and food. This difference in the utilisation of communal lands correlates highly with the socio-economic status of participants and their proximity to major metropolitan areas.

\section{Harvesting frequency}

Data from this study clearly indicate that a fixed protocol as to how often wild plants should be collected did not exist (Figure 2). Plants were collected throughout the year, and seasonality only played a role when harvesting fruits. However, harvesting frequency in Ga-Sekgopo village (42\%) was higher than that of Monyaneng (34\%). A significant number of participants in Ga-Sekgopo harvest plant material almost on a daily basis compared to those residing in Monywaneng, who collect once a week. This might be due to the difference in lifestyles between participants, mostly influenced by locality. For instance Monywaneng village is located closer to the city of Polokwane, and people in this village regularly use electricity as their primary source of energy and paraffin for cooking except during winter. In contrast Ga-Sekgopo is situated far from urban areas, and the majority of people are dependent on wood as a source of fuel for cooking and for the provision of other needs on a daily basis.

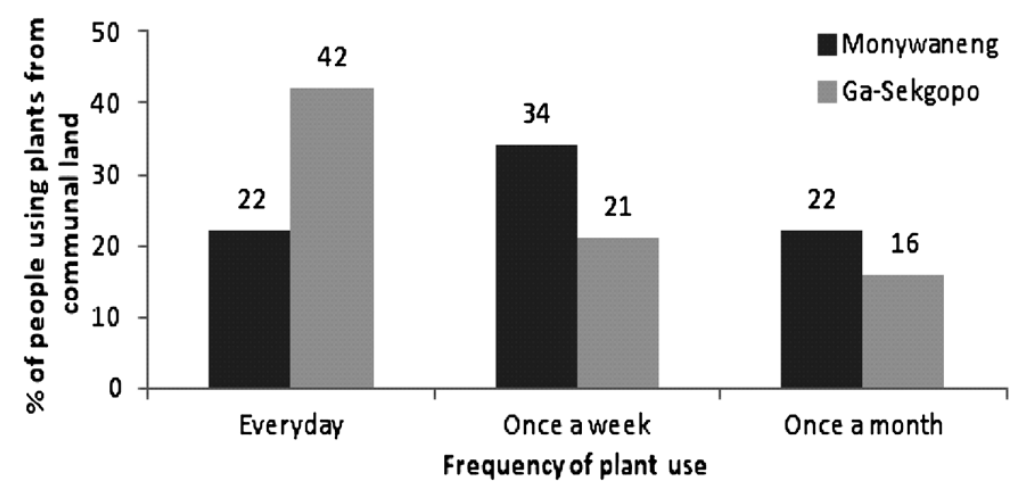

Figure 2 Percentages of harvesting frequencies between Monywaneng and Ga-Sekgopo villages. 


\section{Local management of plants}

Traditional rules and regulations (Table 2) are the only adopted strategies for the management of plants in the studied villages. The most common ones were restriction of people from entering some areas of communal lands, cutting green plants, cutting trees in the graveyard, soil collection in the communal lands, harvesting of some species during certain seasons, exclusive harvesting of leaves of certain species, and collection of lateral roots from plants used medicinally. Some of these traditional rules and regulations are universal amongst different ethnic groups in African countries [9,40-45].

Participants in the current study indicated that chiefs and indunas (headmen of the village) enforce the compliance rules and regulations in villages. Most participants indicated that they are restricted from entering certain areas of communal lands, as these are considered sacred, and viewed by traditional leaders as a way of preserving cultural heritage. Another control mentioned by participants was the cutting of green plants in the wild, and felling of trees in graveyards. Cutting of green branches and twigs of $P$. capensis (in the wild) was prohibited, with only harvesting of its fruits allowed. Similarly, felling of A. karroo, A. rehmanniana and $P$. africanum from the graveyard was forbidden, because graveyards are believed to be the home of the ancestors, who bring peace in the village. Thus collection of any

Table 2 Local traditional rules and regulations used to manage plant resources in the surveyed villages

\begin{tabular}{|c|c|c|}
\hline Traditional rule and regulations & Ga-sekgopo & Mongwaneng \\
\hline No cutting of green plant & + & + \\
\hline No cutting trees in the graveyard & + & + \\
\hline No soil collection in the communal land & + & + \\
\hline $\begin{array}{l}\text { No plant collection in times of initiation } \\
\text { schools }\end{array}$ & + & - \\
\hline $\begin{array}{l}\text { Woman are not allowed to collect plants } \\
\text { during menstruation periods }\end{array}$ & + & - \\
\hline $\begin{array}{l}\text { Pregnant woman are not allowed in } \\
\text { communal lands }\end{array}$ & + & - \\
\hline $\begin{array}{l}\text { Some species are only harvested during } \\
\text { certain seasons }\end{array}$ & + & - \\
\hline $\begin{array}{l}\text { Some species are only harvested for } \\
\text { their leaves }\end{array}$ & + & + \\
\hline $\begin{array}{l}\text { Certain parts of communal lands are } \\
\text { restricted for collection }\end{array}$ & + & + \\
\hline Only small quantity of plant are collected & - & + \\
\hline Only lateral roots of plants are collected & + & + \\
\hline Stem bark is harvested on one side & - & + \\
\hline $\begin{array}{l}\text { Permit required for harvesting firewood } \\
\text { and timber }\end{array}$ & + & - \\
\hline
\end{tabular}

KEY; + : Traditional rule and regulation used, - : Traditional rule and regulation not used. sort of natural resource in this area will upset them, and consequently there will be no peace in the village. This cultural belief and practice is widespread in southern Africa $[9,41,46]$, and has some positive impacts on conservation and sustainable use of resources.

This study found that the harvesting of bark for medicinal purposes is also regulated under local and traditional law. For example harvesting of stem bark of S. birrea is exclusively on the eastern side. This is due to the perception that bark harvested from this side of a tree contains more healing ingredients due to the belief that westerly winds carry healing powers. This traditional method of harvesting prevents trees from being ring barked and thus aid in their conservation.

Similarly, only lateral roots from medicinal species such as P. obliquum and G. senegalensis, and leaves of $L$. javanica can be harvested under customary law, a phenomenon also observed by Mabogo [4] in the Venda region of the Limpopo Province. This practice causes less impact on the survival of an individual species since the tap root is not affected. The practice of harvesting leaves for medicinal purposes are seen $[35,42,47]$ as more sustainable because it causes less structural impact on a plant. Thus the current study affirmed that traditional rules and regulations can play an important role in the conservation and the management of wild plant resources. However, this can only happen if these rules and regulations are adhered to.

\section{Attitudes on traditional rules and regulations}

Just over two thirds (67\%) of participants noted that they are not happy with current traditional laws that are used to manage communal plant resources in their villages. They noted that these laws are not effective, simply because users of these resources do not comply with them, leading to overexploitation. Various reasons have been put forward for this non-compliance; these include, traditional leaders being inexperienced in implementing and enforcing regulations, as well as very young leaders who do not command respect. These factors have led communities to suggest that governmental agencies should play a prominent role in the decision-making process and the management of their communal plant resources. Reasons put forth by those not in favour of governmentled intervention, cite that government officials mostly enforces laws that are not in harmony with their lifestyle. Furthermore, these community members felt that they are not included in the decision making process and thus feel alienated; a finding also reported by Adams [48] and Boonzaaier [49]. Thus it is clear that if government do get involved in the management of natural resources in communal lands, that this should be in an advisory capacity to empower community elders and leaders, both in terms of knowledge and status. 


\section{Conclusion}

The current study concludes that plants still play an important role in the surveyed rural areas of the Limpopo Province. Furthermore, for sustainable plant resources utilization in these areas, various state-sponsored management and conservation strategies must be combined with the use of traditional practice. This can be achieved by the establishment of community-based natural resource management mechanisms. In this mechanism, the community members and their traditional leaders are given full control on management of their plant resources in communal lands, with full support from government. For instance, government employees' who are experts in the field of natural resource management should capacitate the community members, with relevant skills on how to manage communal lands based-natural resource; such as the sustainable methods of harvesting wild natural resource, and different strategies of natural resource management (such as domestication of some plants in home gardens, and the establishments of nature reserve for commonly used plants). Furthermore, they should educate the community members on the benefits of managing natural resource. These will, according to Moeng and Potgieter [50], enable communities to manage their environment on ecological principles and benefit economically from becoming stewards over plant biodiversity. Damn [51] noted that community conservation activities also could lead to the re-establishment of grass roots democracy and the freedom to control their destinies, which would further improve the socio-economic status of communities and by that, benefit conservation.

\section{Competing interests}

The authors declare that they have no competing interests.

\section{Authors' contributions}

MTR and SSS wrote the manuscript. MJP and AM, respectively; helped to finalise manuscript. Field work was executed by MTR. All authors have read and approved the final manuscript.

\section{Acknowledgements}

The authors are grateful to people in Ga-Sekgopo and Monywaneng who participated in this study. Furthermore we thank Mr Solomon Seja Rasethe and Mrs Johannah Mogapu Rasethe for financial support. Bronwyn Egan is acknowledged for the grammatical editing of the manuscript.

Received: 6 December 2012 Accepted: 7 April 2013

Published: 16 April 2013

\section{References}

1. Cunningham AB: African medicinal plants: Setting priorities at the interface between conservation and primary healthcare. People and plants working paper. No. 1. Paris: UNESCO; 1993.

2. Yirga G: Assessment of indigenous knowledge of medicinal plants in Central Zone of Tigray, Northern Ethiopia. Afr J Plant Sci 2010, 4:6-11.

3. Archer FM: Planning with People. Ethnobotany and African Uses of Plants in Namaqualand (South Africa). In Proceedings of the $12^{\text {th }}$ Plenary meeting of AETFAT. Mitt. Institute, Allg. Bot. Hamburg. Edited by Peters CR, Jejoly J; 1990.

4. Mabogo DEN: The ethnobotany of the VhaVenda. MSC Dissertation. South Africa: University of Pretoria; 1990
5. Abebe D, Debella A, Urga K: Medicinal plants and other useful Plants of Ethiopia. Singapore; 2003.

6. Wassihun B, Asfaw Z, Demissew S: Ethnobotanical study of useful plants in Daniio Gade (home-gardens) in Southern Ethiopia. Ethiopian J Bio/ Sci 2003, 2:119-141

7. Shava S: Research on indigenous knowledge and its application: A case of wild food plants of Zimbabwe. S Afr J Environ Educ 2005, 22:73-86.

8. Bekalo TH, Sebsebe DW, Woldemariam ZW: An ethnobotanical study of medicinal plants used by local people in the lowlands of Konta Special Woreda, southern nations, nationalities and peoples regional state, Ethiopia. J Ethnobiol Ethnomed 2009, 5:26. doi:10.1186/1746-4269-5-26.

9. Msuya TS, Kideghesho JR: The role of traditional management practices in enhancing sustainable use and conservation of medicinal plants in West Usambara Mountains, Tanzania. J Trop Conserv Sci 2009, 2:88-105.

10. Legwaila GM, Mojeremane W, Madisa ME, Mmolotsi RM, Rampart M: Potential of traditional food plants in rural household food security in Botswana. J Horticulture Forestry 2011, 3:171-177.

11. Iqbal M: International trade in non-wood forest products. An overview. Rome: $\mathrm{FAO} ; 1993$

12. Van Wyk B-E, Gericke N: People's Plants. Pretoria: Briza Publications; 2000.

13. Ramakrishnan PS: Traditional forest knowledge and sustainable forestry: A north-east India perspective. For Ecol Manage 2007, 249:91-99.

14. Anthony B: The dual nature of parks: attitudes of neighbouring communities towards Kruger National Park, South Africa. Environ Conserv 2007, 34:236-245.

15. Monning HO: The Pedi. Pretoria: Van Schaik (Pty) Ltd; 1967

16. Semenya S, Potgieter M, Erasmus L: Ethnobotanical survey of medicinal plants used by Bapedi healers to treat diabetes mellitus in the Limpopo Province, South Africa. J Ethnopharmacol 2012, 141:440-445.

17. Acocks JHP: Veld types of South Africa. $3^{\text {rd }}$ Edition. Memoirs Botanical Survey South Afr 1988, 57:1-146.

18. Mucina L, Rutherford MC (Eds): The vegetation of South Africa, Lesotho and Swaziland. Pretoria: Strelitzia 19. South African Biodiversity Institute; 2006.

19. Conference Venues South Africa: The climate of the Limpopo Province: Rainfall micro- and macroclimates and temperatures. [http://www.conference-venues.co. za/info/limpopo-climate.html]. Site accessed 04/04/ 2013.

20. M'Marete CK: Climate and Water Resources in the Limpopo Province. Polokwane: Limpopo Department of Agriculture; 2003.

21. International Society of Ethnobiology: ISE Code of Ethics (with 2008 additions). 2009. Online [www.ethnobiology.net/global_coalition/ethics.php]. Site accessed 04/04/ 2013.

22. International Plant Index: 2012. [www.ipni.org]. Site accessed 04/04/ 2013.

23. Semenya SS, Maroyi A: Medicinal plants used by the Bapedi traditional healers to treat diarrhoea in the Limpopo Province, South Africa. J Ethnopharmacol 2012, 144:395-401.

24. Shackleton S, Campbell B, Wollenberg E, Edmunds D: Devolution and community-based natural resource management: Creating space for local people to participate and benefit. Nat Resour Perspect 2002, 76:1-4

25. Shackleton C, Shackleton S: The importance of non-timber forest products in rural livelihood security and as safety nets: A review of evidence from South Africa. S Afr J Sci 2004, 100:658-664.

26. Madubansi M, Shackleton CM: Changes in fuelwood use and species selection following electrification in the Bushbuckridge Lowveld, South Africa. J Environ Manage 2007, 83:416-426.

27. National Forest Act: Act No. 84 of 1998: Government Communication and Information System. Cape Town, South Africa: Government Gazette; 1998.

28. Rampedi IT: Indigenous plants in the Limpopo Province: Potential for their commercial beverage production. PhD Thesis. Pretoria: University of South Africa; 2010

29. Shava S: The use of indigenous plants as food by a rural community in the Eastern Cape: An educational exploration. Msc, Education. Grahamstown: Rhodes University; 2000.

30. Semenya SS, Tshisikhawe MP, Potgieter MJ: Invasive alien plant species: A case study of their use in the Thulamela Local Municipality, Limpopo Province, South Africa. Sci Res Essays 2012, 7:2363-2369.

31. Botes $L$, van der Westhuizen FH, Du Toit L: Phytochemical contents and antioxidant capacities of two Aloe greatheadii var. davyana extracts. Molecules 2008, 13:2169-2180.

32. Runyoro DKB, Ngassapa OD, Matee MIN, Joseph CC, Moshi MJ: Medicinal plants used by Tanzanian traditional healers in the management of Candida infections. J Ethnopharmacol 2006, 106:158-165. 
33. Mathabe MC, Nikolova RV, Lall N, Nyazema NZ: Antibacterial activities of medicinal plants used for the treatment of diarrhoea in Limpopo Province, South Africa. J Ethnopharmacol 2006, 105:286-293.

34. Chinsembu KC, Hedimbi M: An ethnobotanical survey of plants used to manage HIV/AIDS opportunistic infections in Katima Mulilo, Caprivi region, Namibia. J Ethnobiol Ethnomed 2010, 6:25. doi:10.1186/1746-4269-6-25.

35. De Wet H, Nkwanyanaa WN, Van Vuuren SF: Medicinal plants used for the treatment of diarrhoea in northern Maputaland, KwaZulu-Natal Province, South Africa. J Ethnopharmacol 2010, 130:284-289.

36. Ribeiro A, Romeiras MM, Tavares J, Faria TM: Ethnobotanical survey in Canhane village, district of Massingir, Mozambique: medicinal plants and traditional knowledge. J Ethnobiol Ethnomed 2010, 6:33. doi:10.1186/17464269- 6-33.

37. Semenya SS: Bapedi phytomedicine and their use in the treatment of sexually transmitted diseases in Limpopo Province, South Africa. MSc Dissertation Mankweng: University of Limpopo; 2012.

38. Shanley $\mathrm{P}, \mathrm{Luz} \mathrm{L}$ : The impacts of forest degradation on medicinal plant use and implications for health care in Eastern Amazonia. BioScience 2003, 53:573-584.

39. Paumgarten F, Shackleton CM: Wealth differentiation in household use and trade in non-timber forest products in South Africa. Ecol Econ 2009, 68:2950-2959.

40. Haugerud A, Collinson MP: Plants. Genes and People: Improving the Relevance of Plant Breeding. Gatekeeper Series No. 30. London: International Institute for Environment and Development; 1991.

41. Chiwandamira L: Environmental Policy. Harare: Zimbabwe Open University; 2000.

42. Kambizi L, Afolayan AJ: Indigenous knowledge and its impact on medicinal plant conservation in Guruve, Zimbabwe. Afr J Indigenous Knowledge Syst 2006, 5:26-31.

43. Tanyanyiwa Vl, Chikwanha M: The role of indigenous knowledge systems in the management of forest resources in Mugabe area, Masvingo, Zimbabwe. J Sustainable Dev Afr 2011, 13(3).

44. Ndawonde BG: Medicinal Plant Sales: A case study in northern Zululand. MSC Dissertation. KwaDlangezwa: University of Zululand; 2006.

45. Khorommbi KC: The role of Venda culture in conservation: A case study of the inhabitants of the Tshivhase area. M.Tech. Dissertation. Port Elizabeth: Port Elizabeth Technikon; 2002.

46. Luoga EJ: Indigenous Knowledge and Sustainable Management of forest resources in Tanzania. In Information for sustainable natural resources of Eastern, Central and Southern Africa. Workshop Proceedings Arusha Tanzania. Edited by Malimbwi RE, Luoga EJ. 1994.

47. Magoro MD: Traditional health practitioner's practice and the sustainability of extinction-prone traditional medicinal plants. MSc Dissertation. Pretoria: University of South Africa; 2008

48. Adams M, Cousins B, Manona S: Land tenure and economic development in rural South Africa: Constraints and opportunities. London, UK: Overseas Development Institute, Portland House Stag Place; 1999.

49. Boonzaaier C: Rural people's perceptions regarding wildlife conservation-the case study of Masebe Nature Reserve in the Limpopo Province of South Africa. $3^{\text {rd }}$ European Conference on African Studies. Pretoria, South Africa: Department of Anthropology and Archaeology; 2009.

50. Moeng ET, Potgieter MJ: The trade of medicinal plants by muthi shops and street vendors in the Limpopo Province, South Africa. J Med Plants Res 2011, 5:558-564.

51. Damn GR: The conservation game: Saving Africa's biodiversity. Safari Club International. African Chapter. KwaZulu-Natal: Interpak Books; 2002.

doi:10.1186/1746-4269-9-27

Cite this article as: Rasethe et al:: The utilization and management of plant resources in rural areas of the Limpopo Province, South Africa. Journal of Ethnobiology and Ethnomedicine 2013 9:27.

\section{Submit your next manuscript to BioMed Central and take full advantage of:}

- Convenient online submission

- Thorough peer review

- No space constraints or color figure charges

- Immediate publication on acceptance

- Inclusion in PubMed, CAS, Scopus and Google Scholar

- Research which is freely available for redistribution

Submit your manuscript at www.biomedcentral.com/submit
C Biomed Central 